\title{
Defeating IgNorance - IUS aD Bellum Heuristics For Modern Professional Soldiers
}

\author{
- Maciej Zając -
}

\begin{abstract}
Just War Theory debates discussing the principle of the Moral Equality of Combatants (MEC) involve the notion of Invincible Ignorance; the claim that warfighters are morally excused for participating in an unjust war because of their epistemic limitations. Conditions of military deployment may indeed lead to genuinely insurmountable epistemic limitations. In other cases, these may be overcome. This paper provides a preliminary sketch of heuristics designed to allow a combatant to judge whether or not his war is just. It delineates the sets of relevant facts uncontroversially accessible and inaccessible to contemporary professional soldiers. Relevant facts outside these two sets should by default be treated as inaccessible until proven otherwise. Even such a rudimentary heuristic created in this way demonstrates that practical recommendations of MEC-renouncing Just War Theory are not too challenging to follow and still significantly impact a compliant combatant's behavior.
\end{abstract}

Keywords: Just War Theory, military ethics, ethical heuristics, invincible ignorance, moral equality of combatants

Published online: 19 July 2019

The thesis of Invincible Ignorance (I2) holds that the vast majority of soldiers ${ }^{1}$ are fundamentally incapable of knowing whether their side's involvement in a war is just, i.e., whether it adheres to all the Ius ad Bellum criteria as set out by Just War Theory (JWT). According to I2, privates, non-commissioned officers and officers at the tactical and perhaps also operational level - even if intellectually and morally sophisticated enough to understand and apply the principles of JWT - face insurmountable epistemic limitations which prevent them from being able to gather enough relevant information about the justness of their war by the time they are ordered into battle and must decide whether to partake in the conflict. Dating back to at least the $13^{\text {th }}$ century, the concept of I2 was further developed by the $16^{\text {th }}$ century Spanish philosopher Francisco de Vitoria ${ }^{2}$ and became

\footnotetext{
Maciej Zając

University of Warsaw

Institute of Philosophy

Krakowskie Przedmieście 3

PL-00-927 Warszawa

email: maciekzajac1@gmail.com

${ }^{1}$ For reasons of linguistic convenience, I will use the terms "soldiers," "combatants," "warfighters" and "military personnel" interchangeably to signify all uniformed members of various military organizations regardless of the branch they belong to, as is customary in JWT scholarship, while being fully aware that in the context of many military traditions this would constitute a tremendous faux pas.

${ }^{2}$ Sola (2009): 49-51
} 
more or less accepted as a correct description of a rank-and-file combatant's epistemic status until the $20^{\text {th }}$ century (at least within Europe - the hyper-politicized soldiery of the American Revolutionary and Civil Wars do not seem to fit the notion very well). ${ }^{3}$

Discussions of I2 were themselves embedded in a wider debate on the moral character of an ordinary soldier's participation in an unjust war, or on the so-called principle of the Moral Equality of Combatants (MEC). Their relevance to its overall outcome depended on the perceived strength of non-epistemic arguments in favor of the MEC, - i.e. arguments intended to show that an ordinary soldier is allowed to participate in an unjust war even if he is fully aware of its being morally wrong. These arguments involved, but were not limited to, appeals to the moral power of state, national/communal authority and solidarity, (e.g., the moral power of military orders, oaths, allegiance or honor, and the right to defend oneself and others from deadly violence), conceptualizing war as a freely undertaken mass duel, entailing renunciation of their own human rights by combatants of both sides, as well as pragmatic and consequentialist endorsements of the MEC as a bulwark against wartime barbarism. Chapter 3 of Michael Walzer's seminal Just and Unjust Wars constitutes an intellectual high-water mark of non-epistemic argumentation ${ }^{4}$ and a focus for a wave of MEC-renouncing criticism. ${ }^{5}$ Although, not all scholars of JWT were so quick to discard the MEC, only a minority were willing to bite the bullet and hold to non-consequentialist non-epistemic arguments. ${ }^{6}$ The strongest versions of the MEC - offering soldiers automatic justification, permission, or a blanket excuse for their participation in unjust wars - depended on precisely such arguments. As a result, the contemporary debates on the MEC have shifted onto the grounds of subjective permissibility, context-dependent excuses, moral culpability and legal liability; returning critical importance to deliberations concerning I2. ${ }^{7}$

The shift towards context-dependent deliberations on soldiers' epistemic perspectives generates one more welcome development - it allows the long-neglected moral interests of soldiers themselves to come to the fore. Since modern armed forces rely mostly on modestly-compensated volunteer professionals, it stands to reason that many if not most of the troops are motivated at least partially by normative concerns. At least some of these men and women are not out there to perform barely permissible or barely excusable deeds, but rather, to make a significant moral contribution. Consequently, soldiers have an obvious interest in their contributions being truly worthy of the sacrifices they entail. If someone profits by an unjust war, it is surely not the ordinary soldier. In fact,

\footnotetext{
${ }^{3}$ McPherson J. (1997).

${ }^{4}$ But not the high-water mark of the MEC, a principle badly undermined by the moral experience of the Vietnam generation - an experience which spurred Walzer himself to write his book.

${ }^{5}$ Exemplified but not exhausted by Ceulemans (2007); Lang (2011); McMahan (2006): 377-393; McPherson L. (2004); Rodin (2007); Wertheimer (2007).

${ }^{6}$ Benbaji (2011); Christopher (1995); Parsons (2012); Walzer (2006).

7 MEC-renouncers also managed to justify all the traditional elements of in bello justice, and prudent post bellum policies - such as POW immunity from harm, or non-liability of rank-and-file unjust combatants for Ius ad Bellum-related post-war prosecution - without relying on the MEC. Rodin (2007) in particular demonstrated how denying unjust combatants permission and excuse for, among others, inflicting collateral damage to further their unjust cause, what he calls "restrictive asymmetry" in bello does not result in "permissive asymmetry," only combatants gaining privileges to stretch Ius in Bello rules.
} 
military personnel have a vested interest in there being only absolutely-necessary wars as laid out by the criteria of JWT. It is therefore vitally important for soldiers to be able to verify the moral character of the wars they fight and to learn whether they themselves can do so more or less reliably. Unless they can do this, they undertake a very serious moral risk by joining the armed forces - a risk that in many cases may be too high to be permissibly undertaken ${ }^{8}$ or that may in the very least result in making military service a morally unattractive option when compared with the alternatives.

\section{Goals and Methods}

Given the technology-driven improvements in access to relevant information, advances in public education and moral awareness, and the general rise in openness within many contemporary societies, the notion of I2 should be reexamined. A part of this task has been already performed by Andrew Sola, who looked at ten different kinds of ignorance mentioned in JWT scholarship as jointly constitutive of I2. Sola finds that some of these types are "historically dated" - that is, out of touch with subsequent advances in ethics and moral sensibilities while other types are subject to becoming irrelevant due to the "shifting epistemological landscape" - i.e. the aforementioned progress in the public accessibility of information, learning, and moral literacy. Yet another class is described as "temporal restraints" - holding for certain phases of a war such as its usually chaotic beginning, but not in the latter stages. ${ }^{9}$ Sola views his work as a part of a "larger project ... of identifying factors that should be included or excluded in framing the spectrum ... of knowledge and ignorance to be created to determine reasonable expectations we can place on soldiers' knowledge" ${ }^{10}$

I intend this paper to contribute towards furthering Sola's project by taking specific Ius ad Bellum criteria and establishing what a soldier must know and what he cannot know about his side's adherence to these criteria in virtue of knowledge he is required to possess anyway as a military professional and as a citizen performing his civic duties with a minimum of diligence. In performing such an analysis, I will assume a level of information-gathering literacy normally attainable in a digital society, and a level of moral development and sensibility sufficient for general functioning in liberal society.

Out of the six traditional conditions of ad Bellum justice, I postulate three; Probability of Success, Last Resort and Right Intention; for the purposes of the soldier's heuristic, to be reducible to other conditions or altogether disposable. I claim that the first condition which ought to be deliberated upon by combatants is that of (Minimally) Legitimate Authority. Soldiers possess all of the relevant knowledge necessary for awareness of non-compliance with MLA - and they possess it necessarily qua soldiers. (I also claim this of the in bello aspect of the Proportionality Condition, while stating that in its broader, ad bellum, aspect only the most obvious breaches of this requirement

\footnotetext{
${ }^{8}$ One could argue that those who decide to fight a war of an unknown moral status may be more culpable than those taking up arms in a mildly unjust conflict; the average amount of harm done by the former may be far greater.

${ }^{9}$ Sola (2009): 61-62

${ }^{10}$ Ibidem: 62; Zupan (2007).
} 
could be detected by lower-ranking combatants.) As for Just Cause, I believe that only overtly unjust causes are clearly identifiable to soldiers in the absence of epistemic access to their governments' hidden agendas and given the circumstances of genuine doubt under the fog of war.

The exact understanding and scope of each of these criteria is the subject of controversy among theorists ${ }^{11}$ - I will address these in sections devoted to each individual criterion. While the six requirements are usually enumerated in the above-mentioned order, fulfillment of each and every one of them is considered necessary for a war to be just. This traditional order reflects the heuristics intended for very well-informed observers (perhaps even ideal ones), and is aimed at streamlining their judgment, e.g., the absence of a just cause makes deliberations on the given war's chances of success pointless from an ethical standpoint.

The perspective of lower-ranking soldiers is far from such a privileged viewpoint. I therefore reshuffle the ad bellum criteria to reflect the order in which ordinary soldiers acquire information relevant to ad bellum judgments. For some of the criteria, soldiers may not reasonably expect to get sufficient information until after they must decide whether or not they will engage in the war. In these cases, such engagement is by default permissible pending appearance of relevant defeaters.

While such an epistemic analysis is needed for eventual creation of a viable, comprehensive and quick-to-apply ad bellum heuristic ${ }^{12}$ for rank-and-file combatants, I cannot accomplish this task in a single paper. What I can do is - in accordance with the "ought implies can" rule - to sketch the upper- and lowermost epistemic limits of such a heuristic's performance and therefore the limits of an individual combatant's culpability for Ius ad Bellum violations and the epistemic conditions of subjective permissibility for participation in an unjust war. Identifying aspects of Ius ad Bellum justice that are clearly within or outside the epistemic reach of a rank-and-file soldier will serve to demonstrate that MEC-renouncing JWT, when applied in practice, does not unreasonably burden ordinary combatants. It will also show that if complied with, the prohibitions imposed by a MEC-renouncing theory cause non-trivial and much desired change in combatants' behavior.

\section{(Minimally) Legitimate Authority}

"All talk of justice regarding war must revolve ultimately around legitimate governance," insists Brian Orend. ${ }^{13}$ The first purpose of ethical politics, and therefore of just war, is the realization of human rights within one's political community. A political entity capable of realizing those rights to a minimal ethically required extent is known

${ }^{11}$ McMahan (2004); Orend (2013); Walzer (1992).

${ }^{12}$ For the purposes of this article I will define 'heuristics' as a set of 'rules of thumb' designed to render mostly correct judgments on complex subjects in conditions not conducive to competent reasoning, such as severe time pressure, stress, imperfect access to relevant information and the presence of active manipulation; all of which are factors detrimentally impacting a soldier's ability to know the moral character of the war.

${ }^{13}$ Orend (2013): 37. 
as a minimally just state. According to Orend, it need not be a national government, let alone a nation state - super- and supra-national entities, proto-states, factions within a civil war and national liberation movements also fit within this category, provided they fulfill the following criteria: 1) they are generally recognized as minimally just by other minimally just states and by their own population, 2) they avoid violating the rights of other minimally just states, and 3) they make every reasonable effort to satisfy the human rights of their own population. ${ }^{14}$

However, one need not go quite so far as Brian Orend. Let me propose a more permissive definition of the condition of (Minimally) Legitimate Authority (MLA): a political entity fulfills MLA if it does not violently engage in regular or widespread suppression of any population's human rights, nor does it prevent existing or arising structures capable of promoting those rights from doing so.

I must stress that such widespread, violent suppression of rights need not manifest itself in specific violent actions - it may be effected by a palpable and institutionally-grounded threat of severe and widespread violence. A government that stays in power by threatening its own people does not have the capacity for making sound moral calls and acting on their basis. The threat does not even have to be a decisive factor in stabilizing a given government; it is enough $\mathrm{h}$ for it to be plausible and palpable. The Assad regime offers itself as a perfect example. Between the massacre of Hama and other accompanying atrocities, (committed by Hafez al-Assad in 1982, and the massacres committed by his son Bashar from 2011 onward), Syria was a police state breaching basic human rights of its citizens on a daily basis, although, not on a scale that would in itself justify a humanitarian intervention by a foreign power. As proven by the events of the Syrian Civil War, the regime's restraint was conditional on the peoples' submission to its criminal rule. Once the people had risen to demand their rights, the ever present threat of mass violence was actually fulfilled. The regime was willing and able to engage in massacres of peaceful opponents at any given moment. ${ }^{15}$

If a given political entity violates MLA thus understood, it is fair to say that the political community under its rule or influence would be better off starting to build their state anew, as was the case with Germany in $1945 .{ }^{16}$ Consequently, such a state has no moral reason to exist, let alone to demand sacrifices of life and limb to defend its existence, and thus cannot justly engage in wars. It follows that MLA has to take formal and temporal precedence in any JWT heuristic because its non-fulfillment eliminates a combatant's moral reason for going to war.

Two points need to be emphasized here. Firstly, MLA as I have defined it has nothing to do with privileging some forms, levels or genealogies of political organiza-

\footnotetext{
${ }^{14}$ Ibidem: 37-39.

${ }^{15}$ Another, even more brutal example, was the relative non-resistance of Jewish populations in Third Reich ghettos. These men and women followed German laws not because they saw as them legitimate but because they knew how real and imminent the threat of extermination was in cases of non-compliance.

${ }^{16}$ Putting it yet another way, failing this condition makes a state morally liable to domestic insurrection or foreign humanitarian intervention - provided these can satisfy the rules of proportionality and sufficient probability of success.
} 
tion; rightly criticized by Cecile Fabre, among others. ${ }^{17}$ Far from ignoring such criticism, my definition incorporates the values behind it and makes them a cornerstone of the condition. Secondly, the word "minimally" should be taken to heart. Just as otherwise fallible men can be just soldiers, otherwise flawed governments can nevertheless stand for justice in the course of particular armed conflicts (think of colonial Britain and the racially segregated US in World War II). In the context of JWT, "legitimate authority" refers only to a minimal required capacity for being an instrument of justice.

How is a soldier to know whether the regime he serves is a minimally just one? The answer is that if it were not, he would soon learn both - as a subject and a tool - of substantial rights violations. Use of the military as a tool for widespread human rights suppression will not go unnoticed by its members. Getting an army ready to turn on civilians is not an easy task. It requires substantial indoctrination and/or coercion, neither of which can be achieved without its subjects gaining knowledge thereof. ${ }^{18}$ Prior to issuing a criminal order, an unjust regime needs to be reasonably sure that such an order will be followed. Consequently, the soldiers are required either to indicate their readiness to follow it or to show their inability to resist forms of coercion that would be used against them in cases of their non-compliance - in fact, the daily level of oppression directed at them usually goes beyond that affecting an average member of the civilian population. That does not mean that the soldiers have to receive explicit instructions - but neither do mafia hitmen. The regime may value discretion and deniability for the sake of appearances or in anticipation of its eventual fall from power. That does not preclude its criminal intentions from being universally known. For the threats of a terrorist government to be effective, they must be universally known and considered plausible by most. It follows that the soldiers have epistemic access to the facts about an oppressive regime both as its functionaries and as members of the terrorized public, and therefore may not claim ignorance of MLA breaches.

This positive, or at least non-detrimental impact on the human rights situation, coupled with regime-level capacity for being an instrument of justice, forms the moral component of MLA. Yet there is also another, procedural one. This aspect of legitimacy requires the command to engage in war to come via a legally established chain of command and from a person or a collective body fully authorized to give such orders within the state's legal framework. The power of going to war being centralized in a single collective or individual agent (though perhaps in certain scenarios delegated to some high-ranking subordinates) and flowing through clearly established and strictly upheld channels is a basic requirement of competent political decision-making and of effective military action. It is also a sine qua non condition for the moral deliberation prescribed by JWT. In the absence of such arrangements there are no agents capable of accomplishing ad bellum justice, nor is there an environment capable of fostering considerations thereof.

Rogue colonels, coup-staging juntas, bands of vigilantes, radical clerics or ideologues are usually too weak to mold their followers into an effective fighting force under a reasonable degree of central control, but sometimes they prove strong enough to do so.

\footnotetext{
17 Fabre (2008).

${ }^{18}$ A classical study of the progressive brutalization of Nazi troops by their commanders is offered in Bartov (1991).
} 
In the former case their actions may well constitute acts of war, but not on the behalf of a community their soldiers have obliged themselves to serve and defend. ${ }^{19}$ In the latter case, they become leaders of de facto states (albeit different from the ones their soldiers have originally bound themselves to defend), able to wage wars and are therefore capable of adhering to Ius ad Bellum requirements (even if they could only do so by immediately ceasing their violence and relinquishing all their power).

It follows from the above that only in the service of well-ordered political entities (which, let me stress, need not be states) - and in their service only - that soldiers are capable of waging just wars qua soldiers. Upon being told to engage in a war, a soldier has to ask herself whether her order is issued by the political entity she serves, and in the manner specified by all laws and military regulations. Armies, acting in their own best interest, take measures to train their soldiers in distinguishing genuine, legally binding orders from fake and legally ineffective ones and to provide instructions on the best course of action in cases of doubt or attempted deception. Fulfillment of this heuristic requirement by any rank-and-file combatant is therefore not only possible, but also does not constitute an additional burden since every soldier has to follow it nonetheless for extra-moral reasons.

Both the procedural and moral capacities required for fulfillment of MLA are also necessary for application of other Ius ad Bellum principles. To enter into and conduct just wars governments need to be able to prevent their armies from acting before their deliberations are over, and to control their conduct once the hostilities have begun. In addition, they must not have already demonstrated an unwillingness to respect the values and rights which the principles of JWT are supposed to uphold.

In the absence of fulfillment of these basic and commonsense criteria for legitimacy, a soldier has every reason to suppose the war he is being ordered into is an unjust one and he should consider himself morally prohibited from participation until both procedural and moral legitimacy is (re)established. Conversely, if the criteria for legitimate authority are fulfilled, a soldier gains, ceteris paribus, a tacit warrant to trust in his government's willingness to abide by other principles of JWT.

\section{Proportionality in bello and minimal institutional capacity for exercising it}

To examine compliance with the Proportionality Principle before establishing Just Cause seems problematic if not outright impossible because proportionality is always relative to the moral weight of Just Cause. ${ }^{20}$ Although establishing compliance with Proportionality prior to a war's outbreak is impossible, detecting systemic non-compliance and disre-

\footnotetext{
${ }^{19}$ Acts of violence that would constitute war if performed by a state are not necessarily immoral when performed by individuals or loose organizations - think of those WWII resistance organizations that were not the extensions of their governments in exile nor coordinated and commanded by the Allies. Even some of the soldiers' actions outside their formal role as soldiers need not be unjust, as hinted in McMahan (2006): 391-392. However, issues of private or proto-state violence in the face of organized injustice, while deserving of attention by ethical philosophers, are not within the scope of this heuristic as it is directed at soldiers and other regular combatants - who by definition serve and take orders from a specific political community and do not act freely on their own.

${ }^{20}$ McMahan (2004): 708-709; Hurka (2005): 44-45.
} 
gard for proportionality of actions is not. As military professionals soldiers are aware prior to any conflict of their military's willingness to exercise in bello restraint, and the tools it employs to that end. Without a certain minimal capacity for proportionality in bello there can be no proportionality of any kind. If the armed forces at her disposal are equipped with a properly diverse range of munitions, a commander-in-chief may choose to use them proportionally or not. Yet, if the only kind of munitions at her disposal are nuclear weapons, we know beforehand that there is simply neither the will nor ability for acting proportionally, whether in the ad bellum or the in bello sense. I have decided to examine these institutional aspects of proportionality ahead of others (and ahead of Just Cause) because soldiers have privileged epistemic access to these and - just as with some aspects of (Minimally) Legitimate Authority - their deliberation on these matters may (and should) be performed prior to a conflict's outbreak, in much more conducive conditions, and thus should partially relieve the heavy epistemic burden they will face upon the outbreak of war.

The capacity for proportionality in bello consists of legal, doctrinal and technological means ingrained in the structure and culture of military institutions. The fact that a given military organization is able to act proportionally is no guarantee that they will behave properly, but a lack of such ability is evidence that any action it undertakes will be disproportional to some degree. As with MLA, a soldier needs no information, beyond what she has already absorbed as a part of her peacetime military training, in order to judge her army's capacity for proportional action.

The legal component of capacity for proportionality in bello consists of the relevant provisions of military law, universally binding regulations and procedures, and the rules of engagement issued before particular operations or missions. Any military code of justice should contain prohibitions and obligations in line with the international laws of war. These should be taught and enforced down the ranks. Military regulations and procedures should be crafted to prevent and discourage potentially criminal behavior. Some form of military police and a system of judicial and penal institutions should exist to deal with the violators. Finally, the organizational culture - in both its formal and informal expressions - should be molded to strongly discourage all kinds of war crimes. These should be viewed not only as breaches of positive law, but also as violations of the military code of honor, esprit de corps, the brotherhood-of-arms and the very values the soldiers fight and die for.

Such is the ideal. It may be that ethical whistle-blowers will never be truly welcome and military justice will always somehow be tilted to give uniformed criminals unfair advantage. Such imperfections - engendered by ill-conceived loyalty and biases inherent in the military's specific viewpoint - are to be expected, and when they are present to a tolerable degree they do not turn a just conflict into an unjust conflict on their own. However, universal disregard for the laws of war does precisely that, especially if present as a structural feature. A lack of enforcement mechanisms, an absence of relevant training and a lack of general condemnation of criminal behavior all constitute warning signs. At the same time, persistent violations of the laws of war, especially permission for such violations expressed in orders or rules of engagement, strip the war effort of any pretense of justice. As in the case of violence directed against their own people, 
permission for mistreatment of civilians or prisoners of war needs to be palpable to soldiers if it is to be a part of organizational culture and policy; there is no mistaking it for something else. ${ }^{21}$

While a soldier has full access to the totality of laws and regulations issued and can easily check them for compliance with the international laws of war, he can observe the actual state of affairs only within his own unit. Upon encountering violations, he cannot be sure whether the problem is local and restricted to his platoon or battalion - which would not reflect on the whole army's capacity for fighting well - or widespread. However, as he is regardlessly both ethically and professionally obliged to report any gross violations, he may observe how these are dealt with further up the chain of command and draw conclusions about the general attitudes within the force he serves with. It is therefore safe to say that the violations of the laws of war that are severe and common enough to strip an entire war effort of legitimacy are epistemically accessible to a common soldier.

The legal component of the capacity for proportional action serves to dissuade intentional malice understood as actions whose main or perhaps only objective is to cause harm or do evil. However, in the case of non-terrorist states much more frequently occurring problems are those of in bello proportionality and target discrimination. War is not waged exclusively on the high seas or in the remote deserts; civilian populations and infrastructure are more often than not caught in its cross-hairs. Both doctrinal and technological means are developed with the intention of creating ever more effective tactics and precise weapons, enabling victory without doing more harm than absolutely necessary. Soldiers are not only taught these tactics and the art of operating these weapons, they are also asked for feedback or even for direct participation in the process of perfecting them. Therefore, purely professional considerations put a soldier in a position to know whether her force is undertaking a significant enough effort to avoid causing unnecessary harm.

There is no list of specific tactics and weapon platforms which an army needs to have in its toolbox in order to be sufficiently capable of respecting the rules of proportionality, necessity and discrimination. ${ }^{22}$ Still, every military unit is trained to perform a certain range of tasks in a certain range of environments. If the soldiers are not trained and equipped to adjust their mode of operations upon encountering civilians or vital

\footnotetext{
${ }^{21}$ Attitudes prevalent among some of the American troops serving in the Vietnam War, as described in Hersh (1970), provide a perfect negative example. The existence of "free-fire zones," widespread racism contrary to the spirit of the people-oriented counterinsurgency operations and human body parts worn in plain sight of officers as elements of clothing were all evidence of the war's real character - evidence easily and instantly accessible to everyone present. This atmosphere of widespread criminality is most usefully contrasted with the obviously non-ideal, but nevertheless acceptable conduct of US Marines in the Gulf War, as described in Swofford (2003). Racist language, dehumanization of the enemy, glorification of violence, and substance abuse were still present in the ranks to a degree; but when a violation of the laws of war occurred - e.g. a sniper killed some camels for sport, thus depriving an Arab shepherd of his livelihood - the comrades of the violator reacted with moral and professional condemnation. Proper discharge procedures were put into motion, and there was compensation for the inflicted harm.

${ }^{22}$ There is, however, a growing body of texts asserting that use of certain weapon systems or certain classes of tactics may be required of countries which possess sufficient quantity resources or which enjoy a sufficient advantage over their foes. See Beauchamp \& Savulescu (2013); Luban (2014); Strawser (2010).
} 
peacetime infrastructure, an explanation of that fact is due. Criminal negligence is one such explanation. Another may be a lack of resources or the specialized skills needed to employ them. Again, as a professional, a soldier may be expected to have substantial knowledge of the level of performance which can be realistically achieved in relation to the budgetary situation of the force she is serving with.

While temporary absence of tactical and technological capacities may be excusable, especially in the case of developing or struggling countries, a long-term lack of effort to improve a given military's ability to fight well is indeed criminal. Such a lack of effort will be peculiarly palpable in the officer and NCO schools; failure to instill in its leaders the right doctrinal predilections for proportionality and discrimination in the use of force is an obvious sign that the military is unwilling, rather than simply unable, to uphold Ius in Bello. Similar conclusions may follow from observation of the country's weapons industry and the design bureaus attached to it. If features and properties conducive to better Ius in Bello adherence are not pursued even at the stage of concepts and design proposals, there exists a culture of purposeful disregard and criminal negligence. ${ }^{23}$

Summing up, modern professional soldiers are not only permitted but encouraged, for both moral and extra-moral reasons, to gain full knowledge of the legal, doctrinal and technological means of compliance with in bello justice. Two factors, a lack of such arrangements and encouragement to make use of them constitutes evidence of ill will, criminal negligence and organizational incapacity for fighting well. Since a government bears ultimate moral and political responsibility for the character of its armed forces, these factors provide significant grounds for doubting that government's commitment to the principles of JWT, and thus of Right Intention understood as a disposition to action expressed in, organizational behavior. Consequently, a sufficient degree of incapacity, especially if coupled with a culture of contempt for attempts at compliance, should be treated by the soldier as grounds for considering all wars waged by the regime, with the possible exception of defensive wars waged within its own territory, as unjust by default.

\section{Probability of Success}

So far I have established that soldiers possess sufficient levels of epistemic access to reliably make Legitimate Authority and Capacity for Ius in Bello judgments. They are therefore morally culpable when voluntarily serving illegitimate, criminal governments, as well as when serving governments that grossly and wantonly neglect their forces' capacity for in bello justice. Probability of Success is the last among Ius ad Bellum criteria which military professionals might be expected to judge more proficiently than members of the general public - yet I will argue that this is not the case.

The reason for the above is the very nature of the Probability of Success condition. The condition consists of the absolute prohibition of any military action that is certain to fail in achieving its objectives. Even so, it grants conditional permission for undertaking risky military action provided the good secured by any potential success is proportional to the amount of risk. Such risk is almost never quantifiable and better described as deep

${ }^{23}$ Lucas (2013). 
uncertainty, though very rough estimates may still be possible and are, in fact, attempted in military decision-making theory. ${ }^{24}$ Thus even a very low probability of success cannot be taken as evidence for the war failing this criterion, especially as that probability is itself causally dependent on the soldiers' willingness to fight (and so on their estimate of such probability, leading to a causal loop).

As for obviously futile attempts at war, although the prohibition of participation in futile wars is clear in theory, its practical application by ordinary soldiers is problematic for two reasons. Firstly, defining criteria of "success" for fulfillment of war goals is a task and prerogative of a political rather than military nature, and may be performed only by the highest-ranking officials endowed with a political mandate to do so. In the highly fluid wartime environment a soldier cannot assume that he is up to speed on these matters. He cannot therefore ascertain whether a seemingly desperate action is bound to fail, as he cannot be sure of its actual purpose. The North Vietnamese Tet Offensive was, given the disproportion of firepower between the adversaries, bound to fail in its overt military objectives. Yet, the political goals of the offensive were realized, even though they were not the goals the Viet Cong were told to fight for. The soldier's belief that his mission is futile needs to be composed both of knowledge that the overt goal is unattainable and a lack of conviction that there may be a covert military or political goal that is within reach - e.g., a demonstration of remaining military potential in the hope of being offered better terms of surrender. This in turn is tantamount to a loss of confidence in his military and political leaders and is bound to make the soldier withdraw from the war for extra-moral reasons anyway.

This sheds light on a unique aspect of the Probability of Success Principle. While it may be in one's personal or communal interest to disobey other principles of JWT, going against this one is necessarily against the interest of the soldier and her community. While those in power may wish to fight doomed wars, the people and the troops rarely do. In such cases the pull of self-interest is sufficiently strong to produce ethically correct conviction. On the other hand, the margin of epistemic error is high, and rank-and-file soldiers do not seem to enjoy any privileged epistemic access there - to the contrary, isolated in the remote corner of the battlefield, they may know less about the overall strategic situation than civilians at home. These are strong grounds for believing that allowing rank-and-file soldiers to make Probability of Success judgments would lead more frequently to erroneous grounds for abandoning a perfectly just cause at times of surmountable hardship than to abandonment of a truly hopeless effort. Consequently, I recommend leaving Probability of Success considerations out of the soldier's heuristics.

\section{Just Cause}

Just War Theory insists that only a few kinds of causes qualify as just. ${ }^{25}$ This makes the construction of Just Cause heuristics seem prima facie easy. Familiarity with the types of causes that allow for a just war and knowledge of the character of one's own

\footnotetext{
${ }^{24}$ Williams (2010).

${ }^{25}$ Walzer (1992): 51-108; Orend (2013): 34-48, 71-103.
} 
cause $^{26}$ seem sufficient to assess whether that cause fits any of the admissible categories; the default presumption being that if it is not clearly apparent that the cause belongs to some such category, then it does not. Yet things are not that simple. To begin with, most wars have multiple causes - i.e., morally valid and publicly pronounced reasons for the outbreak and continuous pursuit of war, but also include causally significant events, states of affairs, and motivations of leaders that on their own could not justify going to war. War goals are similarly plentiful, divergent, and sometimes even downright contradictory, such as when there is more than one source of agency on a given side (which given institutional agendas and divisions of power can be true even in a war conducted by a single unified entity, let alone by a loose alliance). Additionally, as McMahan points out, ${ }^{27}$ the aims of a particular war are in flux throughout the duration of the conflict depending both on the circumstances and conscious decisions made by the political and military leadership. Thus, a war that was manifestly unjust in one of its phases may become a paradigm of a just war, and vice versa. The number of such changes in the moral status of a single war does not have a fixed upper limit. Moreover, openly stated causes and war goals can in fact be causally inefficient in the decision to fight while secret ones might be causally essential. Such an agenda being secret does not guarantee that it will also be vile - think of the secret abolitionist agendas behind the pursuit of the American Civil War - just as an openly stated goal is not guaranteed to be noble. There is much epistemic work to do, indeed.

Although the nature of deliberations about Just Cause is very challenging, the epistemic asymmetry between knowing one's cause to be unjust and knowing it to be just creates an opening for a simple, quick to use rule-of-thumb. The presence of overtly stated unjust causes allows one to see clearly that the war, and the participation therein, is unjust. ${ }^{28}$ Even less controversially, a single overtly criminal cause ${ }^{29}$ - such as committing genocide - is enough to make a war unjust, even if mixed with ten just causes. This is so

\footnotetext{
${ }^{26}$ In the age of fake news it is important to add that the cause's character is determined not only by what it claims to be at face value, but also how that claim relates to the facts. One of the most important questions to be addressed by further research is the extent to which facts are still available to soldiers and other members of the public, and to what lengths soldiers may reasonably be required to go in order to avoid being deceived.

27 McMahan (2011): 251.

${ }^{28}$ That is to say such a war is unjust, and I must stress this point, for its initiators - and the decision makers able to strike down the unjust goal from the list of war goals of an already ongoing war - not necessarily that it is unjust for all participants. Whether a participant would be barred from serving in a war with the intention of supporting its just causes only, although aware there were unjust causes on its agenda as well, is a debatable issue - see Tadros (2011).

${ }^{29}$ Both what I call unjust causes and overtly criminal causes are criminal in the sense that pursuing them violates moral law and the UN charter. Yet I find it necessary to distinguish between these. Some unjust causes are unjust because it is deeply wrong to pursue them by means of war, but not because it is wrong to pursue them by any other means. Invading Alsace may be wrong, yet acquiring it via a fair referendum is not. However, there is a subset of unjust causes, such as genocide, that are simply wrong in themselves. While I am certain the addition of the latter kind of cause/goal to a list of causes \& goals - for a particular war - delegitimizes the entire war effort, I do not automatically believe the same about the broader category of unjust causes in cases of wars with multiple causes possessing mixed degrees of legitimacy (one needs to remember that WWII was exactly such a mixed affair, especially on the part of the Soviet Union and the British Empire).
} 
because an overt declaration of a criminal cause for war automatically strips a government of its legitimate authority. Therefore, upon being told via legitimate channels to fight for an overtly criminal cause, it is morally impermissible for a soldier to continue fighting unless orders pertaining to the achievement of the criminal goal are rescinded.

What about secret war causes? To be sure one's cause is just, one needs to know there is no hidden agenda behind the war - too demanding a task for everyone outside the very top strata of the government. This cannot even be required of officers at the operational level, let alone of rank-and-file soldiers. It is true that the existence of hidden war goals is bound to manifest in actions at some point. Still, almost any event originating in a legitimate intention may also be interpreted as originating from an illegitimate agenda. Lamentable events may result from executive incompetence or from the inability of even the best strategists to predict everything that may occur in war. Combatants cannot be required to believe any merely plausible insinuation. Still, if a pattern of action emerges in light of a soldier's professional knowledge - inexplicable by anything other than the existence of a hidden and sinister war goal (or by a level of criminal negligence morally on par with it) - a soldier is morally required to cease fighting until the situation is dealt with.

Thus, soldiers are not culpable if their war fails the requirement of Just Cause if such failure results from either the existence of war goals hidden from them, or overt unjust cause(s) that are not decisively exposed by the time of the soldiers' involvement in a given war because of factual or ethical controversies. ${ }^{30}$ However, soldiers are not permitted to fight for openly-known causes that are unjust by nature, nor are they allowed to fight in cases in which the conduct of war clearly indicates the existence of hidden and unjust war goals, as publicly available information coupled with required professional expertise allows soldiers to be educated on these circumstances.

\section{Proportionality Ad Bellum and Last Resort}

I choose to merge the discussion of these two principles as, for the purposes of the soldier's heuristic, Last Resort may be reduced to Ad Bellum Proportionality (ABP). ${ }^{31}$ The application of the Last Resort condition is highly dependent on factors such as the ethical weight of the case for war, the pace of events, the balance of military power and the kinds of weapons and tactics used. Consequently, the only way in which a combatant can learn about a breach of Last Resort - short of its overt and public renunciation - is the obvious disproportion between the importance of the declared cause and the means used to achieve it, which is a violation of ABP.

A soldier should deliberate on ABP only after establishing that she is serving under a legitimate authority showing sufficient care for the requirements of in bello justice and plausibly claiming to fight for a just cause. Such a government possesses a certain amount of moral credibility which must now be drawn upon. While only certain types of

\footnotetext{
${ }^{30}$ In the absence of the creation of international tribunals or "ethical rating agencies" reliably capable of settling such controversies, combatants have to be permitted to participate in controversial yet not obviously criminal conflicts - see McMahan (2006): 388.

${ }^{31}$ One may argue that it so reduces altogether - see Aloyo (2015).
} 
governments, organizational arrangements and openly declared causes are automatically suspicious from the perspective of JWT, almost every act of war leading to death, injury and destruction on the strategic or tactical level, may and should be met with healthy skepticism regarding its necessity and scope. A greater degree of restraint, precision, care in deliberation, greater sacrifice in defense of the innocent or even in order to spare a misguided enemy: these are not benchmarks to be merely achieved, but ideals to be pursued and surpassed while being never completely achieved (at least not by human soldiers). ${ }^{32}$ Self-doubt in these cases is a sign of healthy morals and strength of character, but it cannot be exercised in real time by troops in combat, even in relation to the thin slice of the battlefield they actually observe, as the soldiers view it without the benefit of the overall strategic context. (This changes significantly in the case of prolonged conflicts, when the time for the emotional and cognitive respite necessary for a measured deliberation are available.)

Apart from means that are obviously disproportional in relation to the declared cause, and situations when a disproportionately strong adversary attacks a much weaker non-aggressive state - without any attempt at solving their quarrel via diplomacy (making for obvious non-compliance with Last Resort), deployed combatants can only judge the in bello proportionality of their own daily conduct, not ABP issues. A careful analysis of actual cases would be required to determine the exact scope of a soldier's epistemic reach in this area, but it should not - with the probable exception of drawnout counter-insurgency conflicts of a stable nature - be considered substantial. Soldiers - especially combat troops - only know of the most obvious breaches of ad bellum proportionality and the Last Resort condition, and therefore in most circumstances cannot be blamed for participation in wars that are unjust for those reasons.

\section{Right Intention}

Right Intention is the last of the Ius ad Bellum principles to be considered. I believe, just as in the case of Probability of Success, that the heuristics should not contain it. However, I have addressed Right Intention from the very beginning - right intention as demonstrated by actions and constituting their cause. Compliance with all other ad bellum conditions - especially minimally-just conduct in all aspects of a given polity's functioning and institutional steps towards Ius in Bello capabilities - constitutes sound evidence of right intention. One struggles to think of possible defeaters that would not also simultaneously act as evidence of non-compliance with other ad bellum conditions. Unjustly-aggressive war plans - previously-undiscovered proof of criminality or criminal carelessness in war, or even an overt and public declaration of evil intent - are all such breaches.

In public matters of great gravity such as war, intentions count only as dispositions for action - if they are proven to reliably motivate an individual or a collective body to act morally, there is nothing more to discuss. Suppose Bill Clinton revealed that his infamous failure to stop Rwandan genocide was actually a personal effort to

$\overline{32}$ Anderson \& Waxman (2013); Beauchamp \& Savulescu (2013). 
curb his own extreme passion for war. Curing one's pathological bloodlust is a moral enterprise, but would that matter in this example? Imagine an opposite scenario: Bill Clinton ordering US troops into Rwanda and having them stop the genocide, halving the number of victims in a proportional, restrained and necessary action. His later confession that the decision was motivated by his lust for war would weigh greatly on our judgment of his moral worth as an individual; yet it would not change our view of the war itself our estimates of the misery it prevented, nor the moral merit of the men and women who served in that war.

The subjective aspect of intention - the inner story of policymakers' decisions accessible only to them and those in whom they confide - is as out of the epistemic reach of soldiers following their orders as anything could be. Immoral intentions of people issuing orders - apart from their visible manifestations in violation of other ad bellum conditions - are thus of no consequence to troops under their command ${ }^{33}$.

\section{Conclusion}

Presupposing soldiers' complete moral and factual ignorance not only grants them carte blanche to participate in grossly and obviously unjust wars, bad as that is; it also demeans them and makes JWT fail in a vital part of its task. Military professionals are not just pawns in others' games. They are individuals capable of moral deliberation and are entitled to only serve governments and causes that are genuinely worthy of the enormous sacrifices asked of them during both war- and peacetime. Just like other professionals dealing directly with the realities of human misery, soldiers are faced with a variety of extremely difficult moral dilemmas that could overwhelm any human being left to herself. This does not constitute a reason to deny soldiers' capacity for correct moral choice, but instead creates an obligation to aid them by collectively creating a proper theory of action for people in their position, along with viable methods for applying that theory as efficiently as possible to actual, specific cases.

Neither denying combatants' moral culpability for the injustice of the wars they fight in, nor burdening them with culpability equal to that of decision makers', are possible stances in applied JWT. The actual degree of soldiers' culpability is situated between the two extremes and depends chiefly on their level of epistemic access to relevant information. To learn what that level is, one must attempt to create a soldier's heuristic: a set of rules intended for rank-and-file combatants to use in field conditions. I did not

\footnotetext{
${ }^{33}$ Interestingly, this could also be the case with intimate knowledge of genuinely noble intentions. Suppose a chief architect of a given war confides in his son - who is to fight on the front-lines - and that knowing his father so well the son can be certain that his father wholeheartedly believes in the principles of Ius ad Bellum and aims to uphold them. Yet the son also knows that once the war starts, his father will hold a lot of unchecked power and be under pressure to use it to further certain national interests at the expense of his moral ideals. Should the son believe his father is up to the task, even though most people in his position were not? As Hansson (2013) points out, in cases like this we are rational if we disregard introspection-derived information about individual moral commitments and take a more detached approach based on what we know about people's usual behavior in such circumstances. Thus, intimate knowledge about current mental states of decision makers would not necessarily warrant belief in them keeping their commitments to justice in war.
} 
create such heuristics - I have only sketched an outline of such heuristics and the lower and upper limits of combatant culpability that follows from this exercise.

I believe that even this preliminary work has far-reaching implications for the Selective Conscientious Objection debate and associated issues. What should soldiers do with the knowledge that their war is unjust? What should our military, judicial and political institutions allow soldiers to do in that case? Should their reaction depend on the degree to which a war is unjust, or the specific reason for which it is unjust? These are certainly topics worthy of further research and reevaluation in light of the findings presented above.

The ethics of war have ignored the moral perspective of the ordinary soldier for far too long, failing to provide advice for her that reflects the actual complexities of her moral dilemmas. Given this, I feel that even the obviously incomplete proposal presented above may be of value. All the individual issues briefly discussed here should be granted much more attention - not only by ethicists, but by military intellectuals, historians, lawyers and the servicemen and women themselves. This interdisciplinary and inter-communal effort is required to finally begin treating contemporary professional combatants as moral agents capable of making - and striving for - ethical decisions in order to choose only the causes and governments worthy of their sacrifice.

\section{References}

Aloyo E. (2015), "Just War Theory and the Last of Last Resort," Ethics \& International Affairs 29 (2): 187-201.

Anderson K. \& Waxman M. (2013), "Law and Ethics For Autonomous Weapon Systems; Why a Ban Won't Work and How the Laws of War Can," URL = https:/ / papers. ssrn.com/sol3/papers.cfm?abstract_id=2250126 [Accessed 07.02.2019].

Bartov O. (1991), Hitler's Army; Soldiers, Nazis and War in the Third Reich, Oxford University Press, Oxford.

Beauchamp Z. \& Savulescu J. (2013). "Robot Guardians: Teleoperated Combat Vehicles in Humanitarian Military Intervention," [in:] Killing by Remote Control. The Ethics of an Unmanned Military, B. Strawser \& J. McMahan (eds.), Oxford University Press, Oxford: 106-125.

Benbaji Y. (2011), "The Moral Power of Soldiers to Undertake the Duty of Obedience," Ethics $122(1): 43-73$.

Berkovich I. (2017), Motivation in War; The Experience of Common Soldiers in Old-Regime Europe, Cambridge University Press, Cambridge (MA).

Ceulemans C. (2007), “The Moral Equality of Combatants," Parameters, 37(4): 99-109.

Christopher P. (1995), “Unjust War and Moral Obligation: What Should Officers Do?," Parameters 25 (3): $4-8$.

Fabre C. (2008), "Cosmopolitanism, just war theory and legitimate authority," International Affairs 84 (5): 963-976.

Hansson S.O. (2017), “Uncertainty and Control,” Diametros 53: 50-59.

Hedges Ch. (2003), What Every Person Should Know About War, Free Press, New York.

Hersh S. M. (1970), My Lai 4; A Report on the Massacre and Its Aftermath, Paperback Edition, Random House, New York. 
Hurka T. (2005), "Proportionality in the Morality of War," Philosophy \& Public Affairs 33 (1): $34-66$.

Lang G. (2011), "Excuses for the Moral Equality of Combatants," Analysis Reviews 71 (2): 512-523.

Luban D. (2014), "Risk Taking and Force Protection," [in:] Reading Walzer, Y. Benbaji \& N. Sussman (eds.), Routledge, New York: 277-301.

Lucas Jr., G. R. (2013), “Engineering, Ethics and Industry: The Moral Challenges of Lethal Autonomy," [in:] Killing by Remote Control. The Ethics of an Unmanned Military, B. Strawser \& J. McMahan (eds.), Oxford University Press, Oxford: 211-228.

McMahan J. (2004), “The Ethics of Killing in War," Ethics 114 (4): 693-733.

McMahan J. (2006), "On the Moral Equality of Combatants," Journal of Political Philosophy 14 (4): 377-393.

McMahan J. (2011), “The Prevention of Unjust Wars,” [in:] Reading Walzer, Y. Benbaji \& N. Sussman (eds.), Routledge, New York: 233-255.

McPherson J. (1997), For Cause \& Comrades; Why Men Fought In The Civil War, Oxford University Press, Oxford.

McPherson L. (2004), "Innocence and Responsibility at War," Canadian Journal of Philosophy 34 (4): 485-506.

Montrose J. (2013), “Unjust War and a Soldier's Moral Dilemma," Journal of Military Ethics $12(4): 325-40$.

Orend B. (2007), "Ius Post Bellum; The Perspective of a Just-War Theorist," Leiden Journal of International Law 20 (3): 571-591.

Orend B. (2013), The Morality of War: Second Edition Expanded and Updated, Broadview Press, Peterborough, Ontario.

Parsons G. (2013), "Public War and the Moral Equality of Combatants," Journal of Military Ethics 11 (4): 299-317.

Pattison J. (2016), “The Case for the Nonideal Morality of War: Beyond Revisionism versus Traditionalism in Just War Theory," Political Theory 46 (2): 242-268.

Rodin D. (2007), "The Liability of Ordinary Soldiers for Crimes of Aggression," Washington University Global Studies Law Review 6 (3): 591-607.

Sola A. (2009), "The Enlightened Grunt? Invincible Ignorance in the Just War Tradition," Journal of Military Ethics 8 (1): 48-65.

Strawser B. (2010), "Moral Predators: The Duty to Employ Uninhabited Aerial Vehicles," Journal of Military Ethics 9 (4): 342-368.

Swofford A. (2003), Jarhead. A Marine's Chronicle of the Gulf War and Other Battles, Simon \& Schuster, New York.

Tadros V. (2016), “Unjust Wars Worth Fighting For," Journal of Practical Ethics 4 (1).

Walzer M. (1980), “The Moral Standing of States: A Response to Four Critics," Philosophy and Public Affairs 9 (3): 209-229.

Walzer M. (1992), "Just and Unjust Wars," Basic Books, New York.

Walzer M. (2006), “Response to McMahan's Paper," Philosophia 34 (1): 43-45.

Wertheimer R. (2007), "Reconnoitering Combatant Moral Equality," Journal of Military Ethics 6 (1): 60-74.

Williams B. (2010), "Heuristics and Biases in Military Decision Making," Military Review 90 (5): 40-52.

Zupan D. (2007), “The Logic of Community, Ignorance, and the Presumption of Moral Equality: A Soldier's Story," Journal of Military Ethics 6 (1): 41-49. 